\title{
Polikromatik, dimorfisme seksual, dan redeskripsi spesies ikan red devil, Amphilophus amarillo [Stauffer \& McKaye, 2002] di Waduk Sermo Yogyakarta
}

\author{
[Polychromatic, sexual dimorphism and redescription species of red devil Amphilophus Amarillo \\ [Stauffer \& McKaye, 2002] in Sermo Reservoir, Yogyakarta] \\ Sitty Ainsyah Habibie ${ }^{\bowtie}$, Djumanto dan Murwantoko \\ Departemen Perikanan, Fakultas Pertanian, Universitas Gadjah Mada \\ Jl. Flora No. 1 Bulaksumur, Yogyakarta 55281
}

Diterima: 19 September 2017; Disetujui: 27 Februari 2018

\begin{abstract}
Abstrak
Red devil telah banyak diteliti karena variasi morfometrik dan kromatofora yang sangat tinggi, termasuk di dalamnya fenomena polikromatisme dan trofik polimorfisme. Penelitian ini bertujuan untuk mengamati polikromatik dan dimorfisme seksual serta mengidentifikasi spesies red devil di perairan Waduk Sermo Yogyakarta. Contoh ikan sebanyak 240 ekor diambil dari hasil tangkapan nelayan selama bulan November 2016-September 2017 dengan menggunakan jaring insang, jala dan pancing. Selanjutnya contoh ikan dikelompokkan berdasarkan warna dan jenis kelamin, yaitu kelompok red devil merah, red devil hitam, dan red devil merah kehitaman. Data karakter morfometrik sebanyak 21 unit diukur pada setiap contoh ikan, sedangkan contoh DNA diambil dari jaringan insang pada masing-masing kelompok ikan sebanyak dua ekor. Data karakter morfometrik dianalisis pembedanya, sedangkan DNA dianalisis dengan BLAST (Basic Local Allignment Search Tools) dari NCBI. Hasil analisis komponen utama dan fungsi diskriminan menunjukkan ketiga kelompok ikan dapat dibedakan berdasarkan karakter yang berada di sekitar kepala. Uji t terhadap karakter morfometrik jantan dan betina pada masing-masing kelompok ikan menunjukkan fenomena dimorfisme seksual. Diagram kanonikal dan dendrogram konsisten mengelompokkan ketiga kelompok ikan tersebut sebagai spesies yang sama, namun terpisah berdasarkan jenis kelamin sehingga sangat nyata terjadi dimorfisme. Hasil sekuensing mitokondria DNA control region menunjukkan seluruh kelompok ikan red devil yang ditemukan di Waduk Sermo merupakan spesies Amphilophus amarillo.
\end{abstract}

Kata penting: Dimorfisme seeksual, mtDNA CR, red devil, Waduk Sermo

\begin{abstract}
Red devil has been extensively researched due to extremely high morphometric and chromatophore variations, including the phenomena of polychromatic and trophic polymorphism. The purpose of this study was to identify and observe the phenomenon of sex dimorphism that occurs in polychromatic red devil species which caught in Sermo Reservoir. Fish sample as much as 240 individual was collected from fishermen catch during November 2016September 2017 by using gill nets, cest nets, and fishing rods. Subsequently, the fish sample was grouped based on color and sex, the namely group of red devil red, red devil black, and red devil reddish black. The morphometric character data of 21 units were measured in each fish sample, whereas the DNA samples were taken from the gill tissue on each species of two individuals. The morphometric character data was analyzed for discriminant distance, while DNA was analyzed by BLAST (Basic Local Allignment Search Tools) from NCBI. The result of the principal component analysis and discriminant function showed the three group of fish can be distinguished by the characters around the head. The T-test of male and female morphometric characters in each fish group showed the phenomenon of sex dimorphism. Canonical and dendrogram diagrams consistently classify the three group of fish as the same species but are segregated by sex so that significantly dimorphism occurs. The mitochondrial sequencing results of the DNA control region show that among the red devil fish group found in the Sermo Reservoir is a species of A. amarillo.
\end{abstract}

Keywords: mtDNA CR, red devil, Sermo Reservoir, sex dimorphism

\section{Pendahuluan}

Ikan siklid (cichlid=bangsa nila), dalam perdagangan internasional dikenal sebagai

$\triangle$ Penulis korespondensi

Alamat surel: ainsyahabibie@gmail.com
Nile Tilapia, merupakan spesies yang sering dijadikan sebagai model sistem evolusi biologis pada beberapa dasawarsa terakhir, khususnya terkait spesiasi spesies (Barluenga et al. 2006). Ikan siklid memiliki keragaman dan evolusi tertinggi bila dibandingkan dengan vertebrata 
lainnya, bahkan dengan jenis-jenis ikan lainnya yang tinggal pada lingkungan yang sama. Hal tersebut diyakini karena pengaruh tingkah laku dan karakter morfologis ikan siklid seperti pengasuhan anak, seleksi jenis kelamin, desain fungsional, serta fenotipik dan polimorfisme yang mendukung terjadinya spesiasi (Stiassny \& Meyer 1999, Salzburger 2009).

Ikan siklid genus Amphilophus di Indonesia dikenal dengan sebutan red devil dan secara global dikenal sebagai midas cichlid. Ikan red devil merupakan spesies asli di beberapa perairan tawar di Afrika dan Amerika. Setiap danau memiliki beberapa spesies red devil asli dengan variasi morfologi, warna, tingkah laku, dan ekologi yang cukup tinggi (Barlow 1973, 1976, Elmer et al. 2010, McKaye 1980, McKaye et al. 2002, Stauffer et al. 2008). Spesiasi red devil telah banyak diteliti karena variasinya yang sangat tinggi baik dalam satu spesies yang sama maupun antarspesies, termasuk di dalamnya fenomena polikromatisme dan trofik polimorfisme (Barlow \& Munsey 1976, Barlow 1983, McKaye et al. 2002, Stauffer Jr. \& McKaye 2002, Barluenga \& Meyer 2004, Barluenga et al. 2006; Stauffer Jr. et al. 2008, Geiger et al. 2010, Barluenga \& Meyer 2010, Kratochwil et al. 2015). Pigmentasi atau warna tubuh menjadi isu menarik yang banyak diteliti saat ini dalam keterkaitannya dengan spesiasi spesies. Secara umum, warna tubuh red devil dapat dibedakan menjadi dua yakni "normal" dan "gold". Individu "normal" memiliki warna tubuh abu-abu hingga hitam, merupakan warna yang umum ditemui pada ikan, sedangkan individu "gold" memiliki warna tubuh jingga hingga merah (Barlow 1983, Dickman et al. 1988, Lin et al. 2010, Henning et al. 2013).

Seleksi seksual dianggap memegang peranan penting terhadap spesiasi dan radiasi adaptif pada ikan siklid (Seehausen \& Van Alphen
1998). Sebagian besar ikan nila menunjukkan fenomena dimorfisme seksual (Kullander 2003). Dimorfisme seksual dapat terjadi karena beberapa faktor seperti relung setiap jenis kelamin, seleksi alam, peran reproduksi yang berbeda dan kompetisi intraseksual yang dapat mendorong perbedaan struktur seksual secara eksternal (Kitano et al. 2007). Fenomena polikromatisme dan dimorfisme seks berdasarkan karakter morfometrik menjadi isu menarik dalam penelitian ini. Identifikasi molekuler dilakukan untuk mengonfirmasi identifikasi secara morfologi. Identifikasi molekuler yang digunakan adalah identifikasi menggunakan DNA Mitokondria dengan target sekuensing (sequencing) yakni mitokondria DNA Control Region (mtDNA CR). Mitokondria DNA Control Region (mtDNA CR) merupakan bagian dari mitokondria DNA yang paling variatif dan berevolusi tiga sampai lima kali lebih cepat dibandingkan dengan bagian lainnya pada mitokondria DNA sehingga dipandang sebagai penanda terbaik yang digunakan dalam identifikasi spesies (Wu \& Yang 2012). Tujuan penelitian ini adalah mengamati polikromatik dan dimorfisme seksual, serta mengidentifikasi ikan red devil di Waduk Sermo Yogyakarta.

\section{Bahan dan metode}

Sampel ikan red devil diperoleh dari hasil tangkapan nelayan di Waduk Sermo Yogyakarta (Gambar 1) pada bulan November 2016-September 2017. Ikan ditangkap menggunakan alat tangkap jaring insang, jala, dan pancing. Sampel ikan red devil jantan sangat sulit tertangkap, sehingga untuk mendapatkan jumlah sampel yang cukup dibutuhkan waktu yang cukup lama dengan berbagai alat tangkap. Ikan yang tertangkap kemudian dipisahkan berdasarkan warna tubuh dan jenis kelaminnya. Jenis kelamin dibedakan 


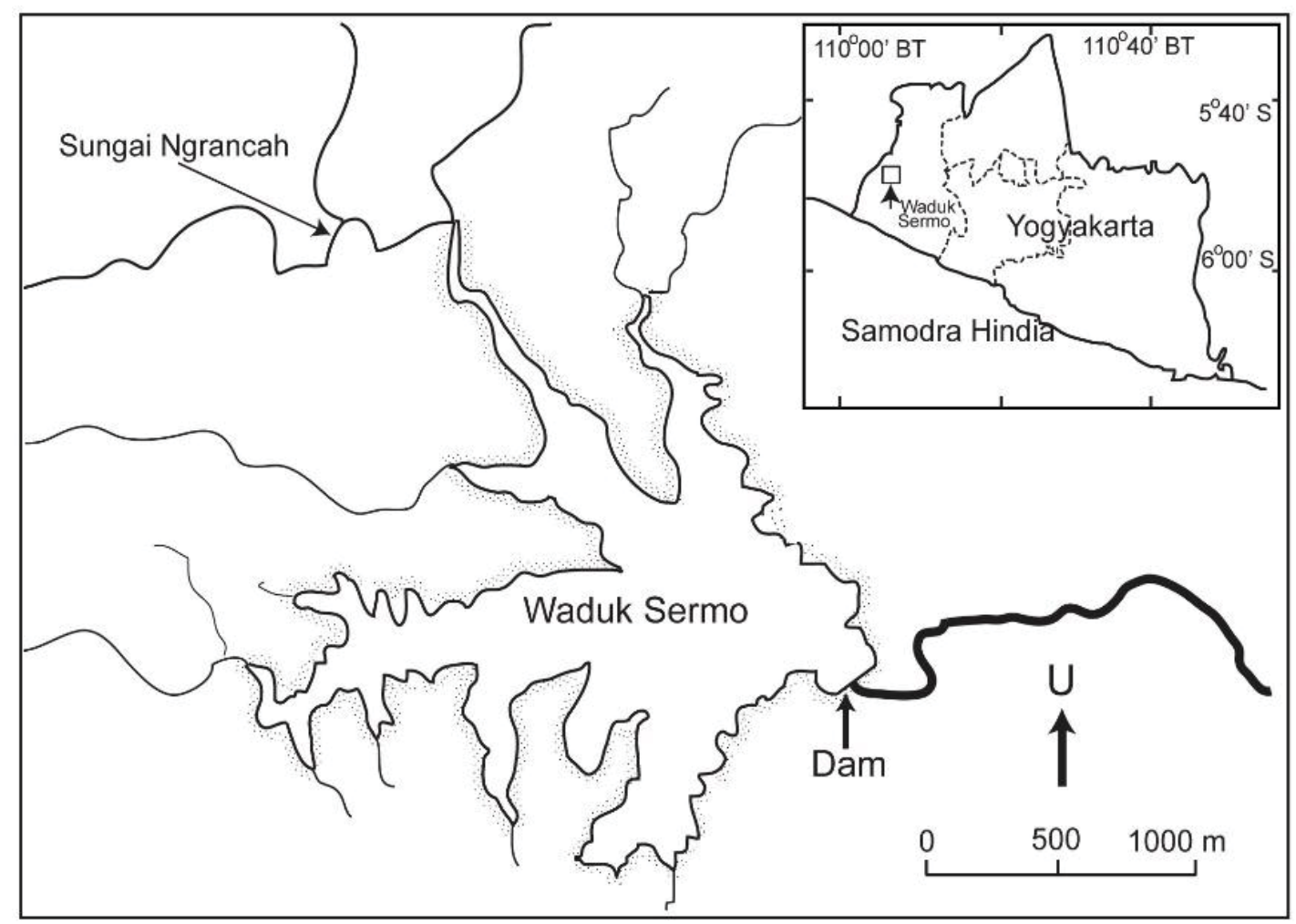

Gambar 1. Peta Waduk Sermo tempat pengambilan sampel ikan red devil

berdasarkan keberadaan testes dan ovarium.

Sampel untuk pengamatan karakter morfometrik pada setiap warna tubuh dan jenis kelamin masing-masing sebanyak 40 ekor. Sampel untuk analisis molekuler setiap warna tubuh dan jenis kelamin sejumlah dua ekor, dilakukan dengan mengoleksi DNA dari jaringan insang, kemudian disimpan di dalam alkohol 70\%.

\section{Pengukuran karakter morfometrik}

Setiap sampel ikan dikelompokkan dan diukur karakter morfometriknya mengikuti pola truss morphometrics. Teknik truss morphometrics dapat mengidentifikasi kemungkinan terjadinya perbedaan morfologi organisme yang mempunyai hubungan kekerabatan dekat, baik antarspesies maupun intraspesies, termasuk perbedaan antara ikan jantan dan betina (Turan et al. 2004). Karakter morfometrik yang dimodifikasi dari Barriga-Sosa et al. (2004) diukur sebanyak 21 karakter (Gambar 2 dan Tabel 1). Setiap data karakter morfometrik yang diukur kemudian dibakukan untuk mencegah terjadinya bias data mengikuti rumus alometrik menurut Elliott et al. (1995) sebagai berikut:

$$
\mathrm{M}_{\mathrm{adj}}=\mathrm{M}\left(\mathrm{L}_{\mathrm{s}} / \mathrm{L}_{0}\right)^{\mathrm{b}}
$$

Keterangan: $\mathrm{M}=$ data morfometrik terukur, $\mathrm{M}_{\mathrm{adj}}=$ data morfometrik terbakukan, $\mathrm{L}_{0}=$ panjang total ikan, dan $\mathrm{L}_{\mathrm{s}}=$ rata-rata panjang total. Parameter b merupakan kemiringan kurva linear $\log \mathrm{M}$ terhadap $\log \mathrm{L}_{0}$ seluruh data. 


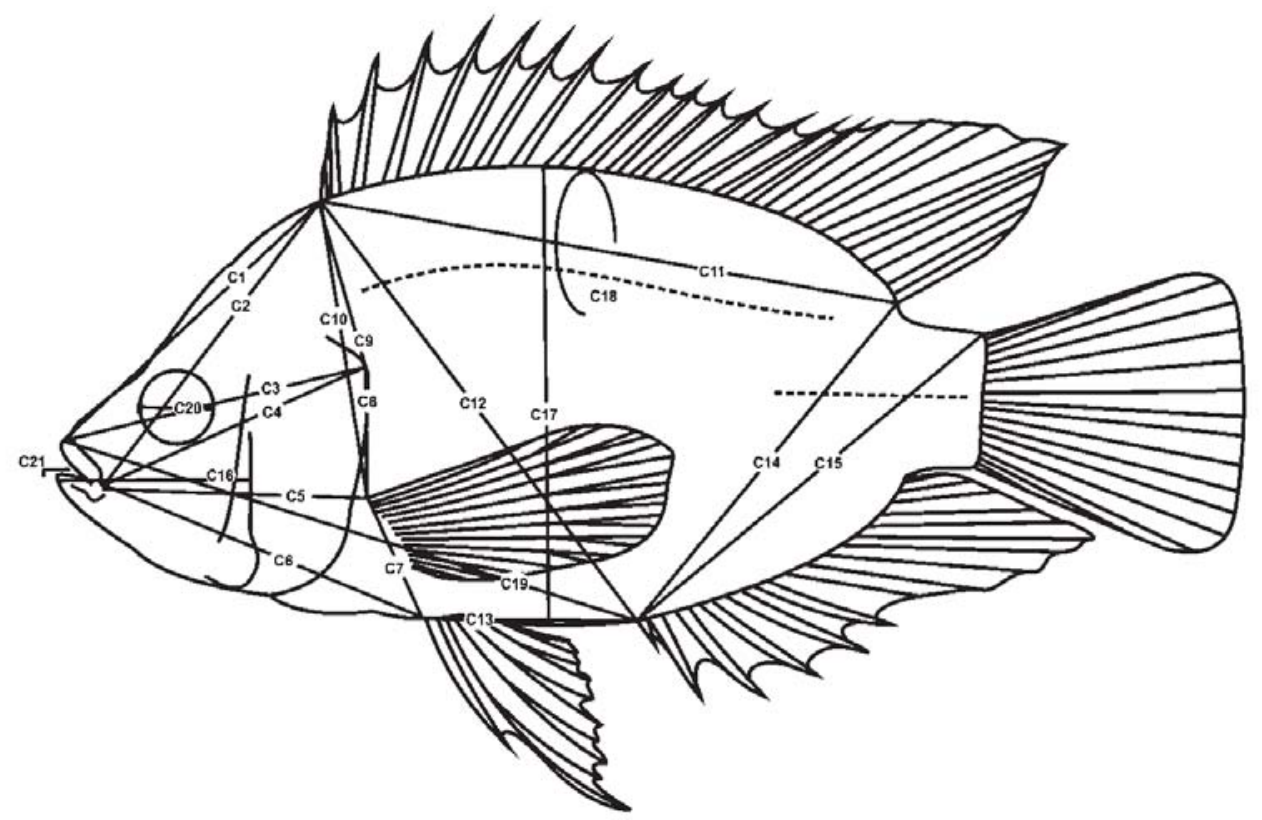

Gambar 2. Karakter morfometrik yang diukur pada setiap sampel ikan red devil (modifikasi Barriga-Sosa et al. 2004). Keterangan gambar disajikan pada Tabel 1.

Tabel 1. Karakter morfometrik ikan red devil (modifikasi Barriga-Sosa et al. 2004)

\begin{tabular}{|c|c|c|}
\hline Kode No & Karakter Morfometrik & Keterangan \\
\hline $\mathrm{C} 1$ & Premaxilla-dorsal spine (PMDS) & $\begin{array}{l}\text { Jarak dari ujung bagian depan rahang dengan sirip } \\
\text { punggung }\end{array}$ \\
\hline $\mathrm{C} 2$ & Maxilla-dorsal spine (MDS) & Jarak dari bagian akhir rahang dengan sirip punggung \\
\hline $\mathrm{C} 3$ & Head length (HL) & $\begin{array}{l}\text { Jarak dari ujung bagian depan rahang atas dengan tutup } \\
\text { insang }\end{array}$ \\
\hline $\mathrm{C} 4$ & Maxilla-opercula (MO) & Jarak dari bagian akhir rahang dengan tutup insang \\
\hline $\mathrm{C} 5$ & Maxilla-pectoral fin (MPF) & Jarak dari bagian akhir rahang dengan sirip dada \\
\hline C6 & Maxilla-pelvic fin (MPV) & $\begin{array}{l}\text { Jarak dari bagian akhir rahang dengan baris pertama } \\
\text { sirip perut }\end{array}$ \\
\hline C7 & Pectoral fin-pelvic fin (PCPV) & Jarak dari sirip dada dengan sirip perut \\
\hline $\mathrm{C} 8$ & Pectoral fin-opercula (PFO) & Jarak dari sirip dada dengan tutup insang \\
\hline $\mathrm{C} 9$ & Opercula-dorsal spine (ODS) & $\begin{array}{l}\text { Jarak dari tutup insang dengan baris pertama sirip } \\
\text { punggung }\end{array}$ \\
\hline $\mathrm{C} 10$ & Pectoral fin-dorsal spine (PFDS) & $\begin{array}{l}\text { Jarak dari sirip dada dengan baris pertama sirip } \\
\text { punggung }\end{array}$ \\
\hline $\mathrm{C} 11$ & Dorsal spine-dorsal ray (DSR) & $\begin{array}{l}\text { Jarak dari baris pertama dengan baris terakhir sirip } \\
\text { punggung }\end{array}$ \\
\hline $\mathrm{C} 12$ & Dorsal spine-anal spine (DSAS) & $\begin{array}{l}\text { Jarak dari baris pertama sirip punggung dengan baris } \\
\text { pertama sirip anal }\end{array}$ \\
\hline $\mathrm{C} 13$ & Pelvic fin-anal spine (PSAS) & $\begin{array}{l}\text { Jarak dari baris pertama sirip perut bagian anterior } \\
\text { dengan baris pertama sirip anal }\end{array}$ \\
\hline C14 & Dorsal ray-anal spine (DRAS) & $\begin{array}{l}\text { Jarak dari baris terakhir sirip punggung dengan baris } \\
\text { pertama sirip anal }\end{array}$ \\
\hline C15 & $\begin{array}{l}\text { Anal spine-top caudal peduncle } \\
\text { (ASTC) }\end{array}$ & $\begin{array}{l}\text { Jarak dari sirip anal dengan pangkal sirip ekor bagian } \\
\text { atas }\end{array}$ \\
\hline C16 & Premaxilla-pre-opercula (PMPO) & $\begin{array}{l}\text { Jarak dari ujung bagian depan rahang dengan tutup } \\
\text { insang depan }\end{array}$ \\
\hline $\mathrm{C} 17$ & Body depth (BD) & Tinggi badan \\
\hline $\mathrm{C} 18$ & Body width (BW) & Lingkar badan \\
\hline C19 & Premaxilla-anal spine (PMAS) & $\begin{array}{l}\text { Jarak dari ujung bagian depan rahang dengan baris } \\
\text { pertama sirip anal }\end{array}$ \\
\hline $\mathrm{C} 20$ & Eye diameter (ED) & Diameter mata \\
\hline $\mathrm{C} 21$ & Length of the mandible (LMD) & Panjang mandibula \\
\hline
\end{tabular}


Identifikasi molekuler

Isolasi DNA terhadap jaringan insang dilakukan menggunakan Genomic DNA Mini Kit Tissue Protocol (Geneaid). Target penanda genetik yang dianalisis adalah mtDNA CR (mitokondria DNA control region) ( $450 \mathrm{bp}$ ). Metode Amplifikasi mitokondria DNA control region mengacu pada Wu \& Yang (2012); Gu et al. (2016) yakni dengan menggunakan pasangan primer ORMT-F, 5'-CTAACTCCCAAAGCTAG GAATTCT-3' dan ORMT-R, 5' CTTATGCAAGCG TCGATGAAA-3'. Penggandaan fragmen (Polymerase Chain Reaction, PCR) dilakukan pada kondisi predenaturasi $\left(94^{\circ} \mathrm{C}\right.$ selama 3 menit), denaturasi $\left(94^{\circ} \mathrm{C}\right.$ selama 30 detik), penempelan primer $\left(54^{\circ} \mathrm{C}\right.$ selama 40 detik), elongasi $\left(72^{\circ} \mathrm{C}\right.$ selama 40 detik), dan elongasi akhir $\left(72^{\circ} \mathrm{C}\right.$ selama 10 menit) untuk meyakinkan proses elongasi berjalan sempurna. Proses PCR ini berlangsung selama 35 siklus. Setelah itu, produk PCR dielektroforesis pada gel agarose 1,5\% dalam 1xTBE buffer untuk memastikan panjang fragmen target penanda genetik yang diinginkan telah teramplifikasi dengan baik. Kemudian, sampel gen disekuensing di Laboratorium $1^{\text {st }}$ Base Malaysia melalui PT Genetika Science Indonesia.

\section{Analisis data}

Data karakter morfometrik jantan-betina yang telah dibakukan, kemudian dilakukan uji-t untuk mengetahui apakah kedua kelompok data bersumber dari populasi yang sama atau berbeda. Hasil uji-t menjadi asumsi jumlah kelompok secara keseluruhan. Selanjutnya, data karakter morfometrik seluruh sampel dianalisis menggunakan piranti lunak IBM SPSS versi 20 mencakup Analisis Komponen Utama, Analisis Fungsi Diskriminan, dan Analisis Klaster.
Urutan nukleotida hasil sekuensing DNA dilakukan CONTIG dengan menggunakan piranti lunak BioEdit. Data hasil penjajaran yang diperoleh kemudian dicocokkan dengan data yang tersedia pada GenBank di NCBI (National Center for Biotechnology Information) dengan menggunakan BLAST (Basic Local Alignment Search Tool). Hasil BLAST NCBI masing-masing sampel disajikan dalam bentuk tabel. Pohon filogenetik disusun dengan menjajarkan sekuen DNA spesies red devil yang teridentifikasi dengan beberapa sekuen DNA kelompok red devil dari GenBank (accession number: AF328853.1, AF328854.1, AY597335.1, GU355726.1, GU355735.1， GU370126.1， HM067614.1, HM183901.1， HM184762.1， HM184892.1, JF784116.1， JF784124.1， JF784144.1, JF784149.1， JX402374.1， JX402378.1 KJ081546.1， KJ562277.1， NC_-15611.1, NC_026918.1). Pohon filogenetik dibuat menggunakan Metode Maximum Likelihood dengan 1000 bootstrap. Sekuen DNA dan penyusunan pohon filogenetik disejajarkan menggunakan piranti lunak MEGA 6.0.

\section{Hasil}

Morfologi spesies red devil

Ikan red devil yang ditemukan di perairan Waduk Sermo Daerah Istimewa Yogyakarta secara umum memiliki bentuk tubuh pipih lateral, jarak sirip perut dengan sirip anal saling berdekatan, bentuk sirip ekor membundar dan terdapat nonong di bagian kepalanya. Berdasarkan warna tubuhnya, ikan red devil dikelompokkan menjadi tiga kelompok yakni red devil merah, red devil hitam, dan red devil merah kehitaman. Ikan red devil merah memiliki warna tubuh merah atau jingga polos, red devil hitam memiliki warna tubuh abu-abu atau hitam polos, dan red devil merah kehitaman memiliki warna tubuh merah 
atau jingga bercampur hitam di beberapa bagian tubuhnya. Perbedaan warna ikan tidak terkait pada jenis kelamin sehingga baik jantan maupun betina ditemukan dalam ketiga fenotip warna tersebut. Kenampakan morfologi luar jantan dan betina masing-masing jenis spesies hampir tidak dapat dibedakan, sehingga pembeda jantan dan betina secara akurat dapat diketahui dengan pengamatan terhadap keberadaan testes dan ovarium pada spesies tersebut melalui pembedahan.

Karakter morfometrik yang diukur pada ketiga kelompok spesies hasil tangkapan sebanyak 21 unit. Ringkasan data hasil pengukuran karakter morfometrik yang sudah dibakukan mengikuti rumus alometrik Elliott et al. (1995) disajikan pada Tabel 2. Data panjang total sebelum dibakukan menunjukkan bahwa spesies red devil merah yang tertangkap memiliki rata-rata ukuran tubuh yang lebih besar dibandingkan dengan red devil hitam dan red devil merah kehitaman. Rata-rata panjang total red devil merah, red devil hitam, dan red devil merah kehitaman jantan dan betina secara berurutan adalah 141, 157, 138, 140, 136, dan 154 mm. Kisaran panjang total hasil tangkapan ikan red devil merah, red devil hitam, dan red devil merah kehitaman berurutan adalah 122-193, 105-184, dan 110-190 $\mathrm{cm}$.

\section{Karakter morfometrik spesies red devil}

Berdasarkan analisis komponen utama 21 karakter morfometrik, didapatkan tiga komponen utama yang dapat menjelaskan $45,42 \%$ dari total varian karakter morfometrik spesies ikan red devil. Sebesar 20,38\% total varian dijelaskan oleh komponen utama pertama (PC 1), sebesar
13,78\% dijelaskan komponen utama kedua (PC 2), dan sebesar $11,26 \%$ dijelaskan komponen utama ketiga (PC 3). Tanda positif pada PC 2 dan PC 3 mencakup karakter morfometrik yang berada di sekitar kepala dan tubuh bagian tengah yakni premaxilla-dorsal spine, maxilla-dorsal spine, maxilla-pelvic fin, pelvic fin-anal spine, premaxilla-anal spine, dan eye diameter. Dengan demikian, berdasarkan hasil analisis komponen utama karakter pembeda antarpopulasi ikan red devil dapat ditentukan oleh keenam karakter tersebut. Distribusi nilai PC 1 dengan PC 2, dan PC 1 dengan PC 3 menunjukkan bahwa populasi ikan red devil merah, hitam, dan merah kehitaman membentuk kelompok yang terpisah berdasarkan jenis kelaminnya. Sebagian besar populasi betina berada pada kuadran I dan IV, sedangkan populasi jantan berada pada kuadran II dan III (Gambar 3 dan 4).

Kombinasi antar analisis komponen utama dengan analisis diskriminan digunakan untuk membedakan kelompok red devil dan mendefinisikan karakter morfometrik yang menjadi pembeda antar populasi. Hasil analisis diskriminan menghasilkan tiga fungsi diskriminan yang masing-masing dapat menjelaskan $81,9 \% ; 6,0 \%$ dan 5,7\% dari total varian karakter morfometrik. Karakter morfometrik pada fungsi diskriminan 1 menyaring dan semakin memperjelas hasil analisis komponen utama, di mana karakter pembeda antar kelompok populasi red devil merupakan karakter yang berada di sekitar kepala. Karakterkarakter pembeda tersebut adalah pectoral finopercula, opercula-dorsal spine, head length, pectoral fin-pelvic fin dan maxilla-opercula. 


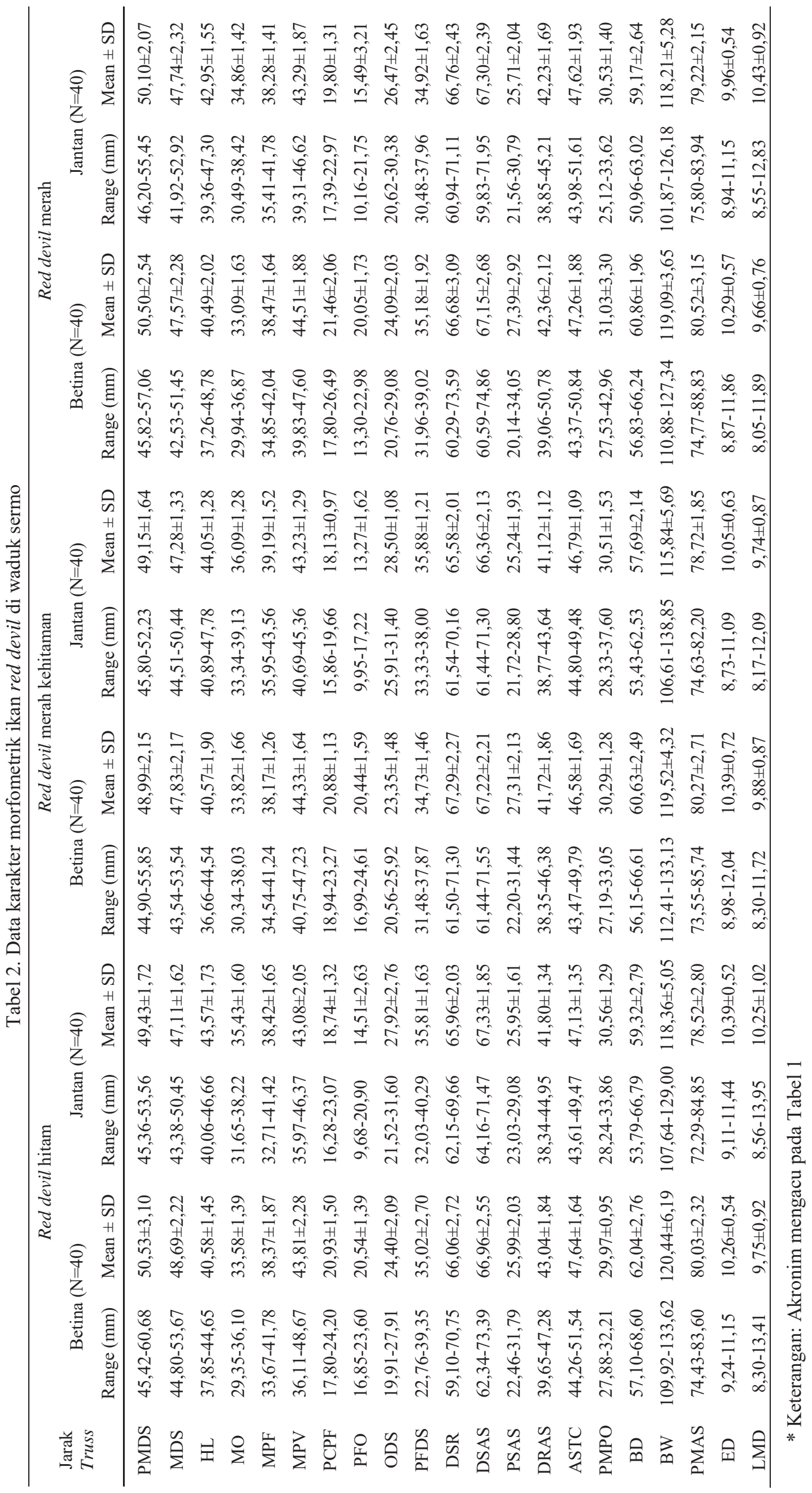




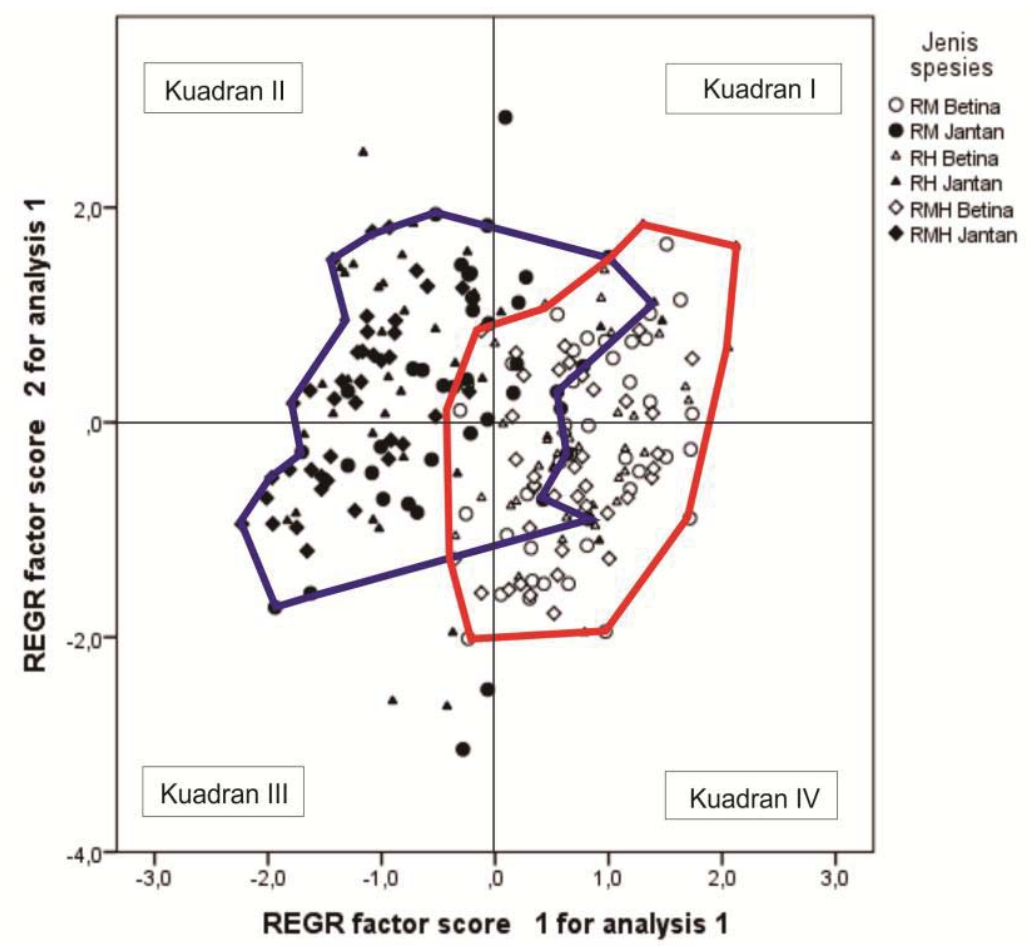

Gambar 3. Scattergram PC 1 dan PC 2 karakter morfometrik spesies red devil di perairan Waduk Sermo. $\mathrm{RM}=$ red devil merah, $\mathrm{RH}=$ red devil hitam, $\mathrm{RMH}=$ red devil merah kehitaman

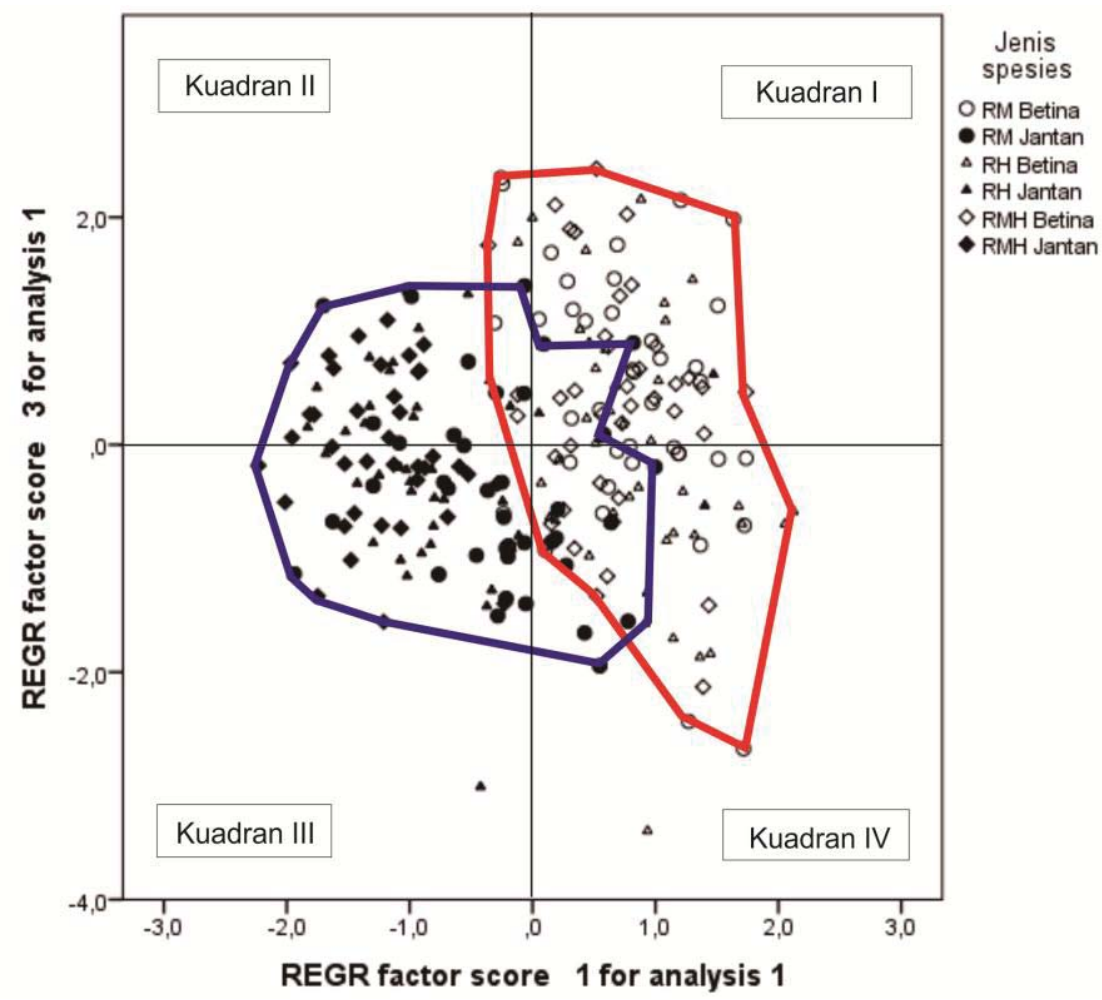

Gambar 4. Scattergram PC 1 dan PC 3 karakter morfometrik spesies red devil di perairan Waduk Sermo $\mathrm{RM}=$ red devil merah, $\mathrm{RH}=$ red devil hitam, $\mathrm{RMH}=$ red devil merah kehitaman 
Sebaran nilai koefisien diskriminan disajikan dalam bentuk diagram fungsi pembeda utama (Gambar 5) yang semakin memperjelas pemisahan antar populasi jantan dan betina pada spesies red devil. Diagram ini mengisyaratkan bahwa spesies red devil yang dikelompokkan berdasarkan warna merupakan satu spesies yang sama, memperkuat hasil karakter morfometrik jantan-betina per spesies dan menegaskan terjadinya dimorfisme seksual pada kelompok spesies ini.
Karakter morfometrik jantan-betina tiap spesies

Hasil pengamatan terhadap 21 karakter morfometrik jantan-betina pada masing-masing kelompok red devil menggunakan uji t menunjukkan adanya beberapa karakter morfometrik yang berbeda secara signifikan pada masingmasing kelompok. Karakter morfometrik yang berbeda tersebut kemudian disusun berdasarkan urutan pembeda utama yang diperoleh melalui analisis diskriminan dan disajikan pada Tabel 3.

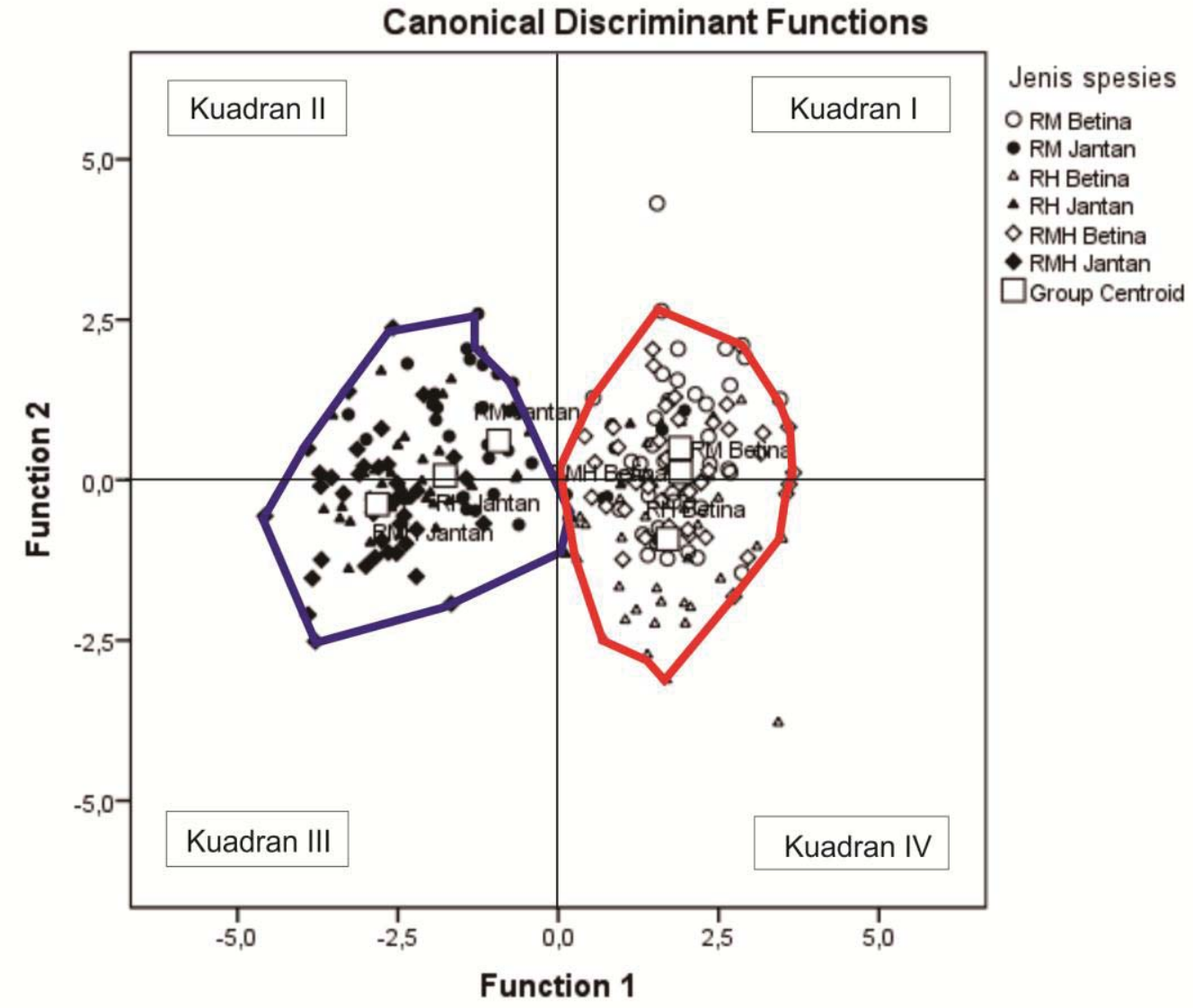

Gambar 5. Diagram fungsi diskriminan kanonikal spesies red devil di perairan Waduk Sermo 
Tabel 3 menunjukkan bahwa karakter morfometrik pembeda utama jantan-betina pada ketiga kelompok red devil yakni pectoral finopercula. Enam karakter morfometrik lainnya yang juga menjadi pembeda antar jantan-betina pada semua kelompok yakni head length, maxilla-opercula, opercula-dorsal spine, pectoral finpelvic fin, dan body depth. Karakter pembeda yang hanya ditemukan pada red devil merah adalah eye diameter, karakter pembeda yang hanya ditemukan pada red devil hitam adalah dorsal ray-anal spine dan premaxilla-pre-opercula, dan karakter pembeda yang hanya ditemukan pada red devil merah kehitaman adalah pectoral fin-dorsal spine, dorsal spine-dorsal ray, dan maxilla-pectoral fin.

Selanjutnya, untuk mendukung data morfometrik yang digunakan dalam pembedaan antar jantan dan betina masing-masing kelompok spesies maka dilakukan perhitungan nisbah pada keenam karakter pembeda utama seperti yang disajikan pada Tabel 4.

Berdasarkan Tabel 4, rata-rata nisbah head length dengan total length (HL/TL) dan opercula-dorsal spine dengan body depth (ODS/BD) pada individu jantan ditemukan lebih besar dibandingkan dengan individu betina. Rata-rata nisbah maxilla-opercula dengan head length $(\mathrm{MO} / \mathrm{HL})$, eye diameter dengan head length $(\mathrm{ED} / \mathrm{HL})$, pectoral fin-pelvic fin dengan body depth (PCPV/BD), pectoral fin-opercula dengan body depth (PFO/BD) dan body depth dengan total length (BD/TL) pada individu jantan ditemukan lebih kecil daripada individu betina.

Tabel 3. Pembeda utama karakter morfometrik tiap kelompok spesies red devil

\begin{tabular}{clll}
\hline Urutan & \multicolumn{1}{c}{ Red devil merah } & \multicolumn{1}{c}{ Red devil hitam } & \multicolumn{1}{c}{ Red devil merah kehitaman } \\
\hline 1 & Pectoral fin-opercula & Pectoral fin-opercula & Pectoral fin-opercula \\
2 & Head length & Head length & Opercula-dorsal spine \\
3 & Maxilla-opercula & Pectoral fin-pelvic fin & Pectoral fin-pelvic fin \\
4 & Opercula-dorsal spine & Opercula-dorsal spine & Head length \\
5 & Pectoral fin-pelvic fin & Maxilla-opercula & Maxilla-opercula \\
6 & Length of the mandible & Body depth & Body depth \\
7 & Body depth & Maxilla-dorsal spine & Pelvic fin-anal spine \\
8 & Pelvic fin-anal spine & Dorsal ray-anal spine & Pectoral fin-dorsal spine \\
9 & Maxilla-pelvic fin & Premaxilla-anal spine & Dorsal spine-dorsal ray \\
10 & Eye diameter & Premaxilla-pre-opercula & Maxilla-pelvic fin \\
11 & Premaxilla-anal spine & Length of the mandible & Maxilla-pectoral fin \\
\hline
\end{tabular}

Tabel 4. Nisbah rata-rata karakter morfometrik red devil di perairan Waduk Sermo

\begin{tabular}{lrrrrrr}
\hline $\begin{array}{c}\text { Nisbah } \\
\text { karakter } \\
\text { morfometrik }\end{array}$ & \multicolumn{2}{c}{$\begin{array}{c}\text { Red devil merah } \\
\text { Jantan }\end{array}$} & Betina & \multicolumn{2}{c}{$\begin{array}{c}\text { Red devil hitam } \\
\text { Jantan }\end{array}$} & \multicolumn{2}{c}{$\begin{array}{c}\text { Red devil merah kehitaman } \\
\text { Jantan }\end{array}$} & Betina \\
\hline MO/HL & 81 & 82 & 81 & 83 & 82 & 83 \\
ED/HL & 23 & 25 & 24 & 25 & 23 & 26 \\
PCPV/BD & 33 & 35 & 32 & 34 & 31 & 34 \\
PFO/BD & 26 & 33 & 24 & 33 & 23 & 34 \\
ODS/BD & 45 & 40 & 47 & 39 & 49 & 39 \\
HL/TL & 29 & 27 & 29 & 27 & 29 & 27 \\
BD/TL & 40 & 41 & 40 & 42 & 39 & 41 \\
\hline
\end{tabular}

* Keterangan: singkatan mengacu pada Tabel 1 
Perbedaan nisbah yang cukup jauh antar individu jantan dan betina ditemukan pada nisbah pectoral fin-opercula dengan body depth (PFO/BD), yaitu red devil merah jantan dan betina (26\% tinggi badan vs $33 \%$ tinggi badan), red devil hitam jantan dan betina (24\% tinggi badan vs 33\% tinggi badan), dan red devil merah kehitaman (23\% tinggi badan vs 34\% tinggi badan). Selain itu, perbedaan nisbah yang cukup jauh antara individu jantan dan betina juga ditemukan pada nisbah jarak tutup insang-baris pertama sirip punggung dengan tinggi badan (C9/C17), yakni red devil merah jantan dan betina ( $45 \%$ tinggi badan vs $40 \%$ tinggi badan), red devil hitam jantan dan betina (47\% tinggi badan vs 39\% tinggi badan), dan red devil merah kehitaman (49\% tinggi badan vs 39\% tinggi badan).

Secara umum, rata-rata panjang total spesies jantan yang tertangkap lebih besar dibandingkan spesies betina pada masing-masing kelompok spesies. Kisaran panjang total betina dan jantan ikan red devil merah yakni 113-174 dan 126-193 mm, panjang total betina dan jantan ikan red devil hitam 105-170 dan 103-184 $\mathrm{mm}$, dan panjang total betina dan jantan ikan red devil merah kehitaman 110-158 dan 121-19 $\mathrm{mm}$.

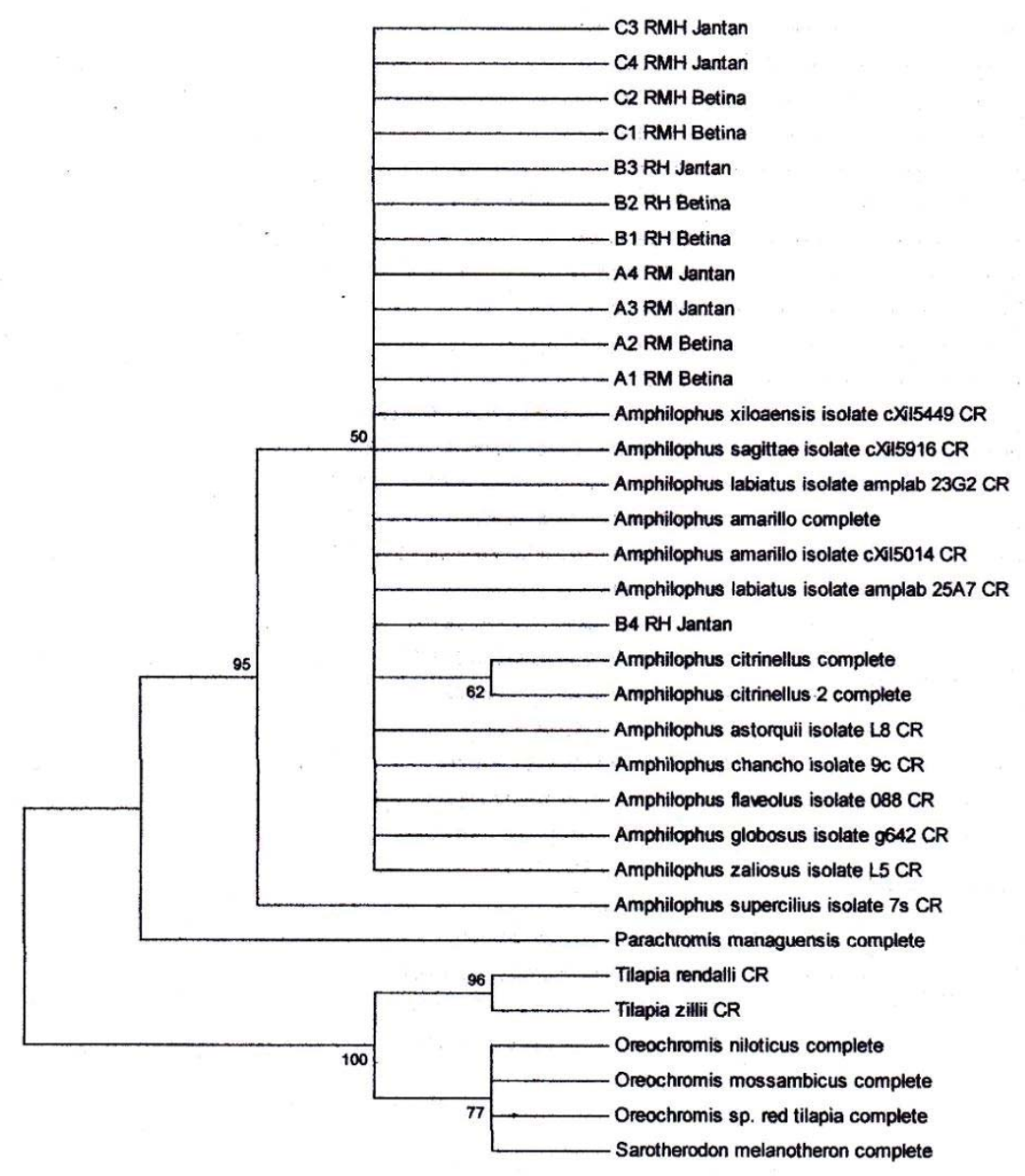

Gambar 6. Pohon filogenetik spesies red devil di perairan Waduk Sermo Yogyakarta menggunakan metode Maximum Likelihood 
Identifikasi molekuler spesies red devil

Hasil sekuensing mitokondria DNA control region menunjukkan bahwa spesies red devil merah, hitam, dan merah kehitaman jantanbetina di perairan Waduk Sermo Yogyakarta memiliki kemiripan tertinggi yakni sebesar 99,80\% dengan spesies Amphilophus amarillo pada GenBank dengan accession number KY315559.1. Tingkat kemiripan tertinggi didasarkan pada pasangan basa identik tertinggi. Hasil identifikasi secara molekuler ini semakin memperkuat hasil analisis karakter morfometrik yang mengidentifikasi seluruh kelompok spesies red devil berdasarkan warna menjadi satu spesies yang sama. Pohon filogenetik menyejajarkan sampel genetik red devil dengan kelompok siklid lainnya yang diperoleh dari Genbank. Terdapat dua clade monopiletik yang terbentuk pada pohon filogenetik (Gambar 6). Clade pertama beranggotakan seluruh kelompok genus Amphilophus dan spesies Parachromis managuensis yang menjelaskan kedua genus ini berasal dari nenek moyang yang sama. Selanjutnya clade kedua beranggotakan kelompok Tilapia.

\section{Pembahasan}

Ikan red devil yang tertangkap di perairan Waduk Sermo Yogyakarta masuk tanpa sengaja ke dalam perairan tersebut. Ikan red devil diduga tercampur dengan ikan nila saat penebaran ikan nila karena bentuk dan warnanya yang hampir mirip. Berdasarkan pigmentasi warna tubuh, red devil di Waduk Sermo dikelompokkan menjadi tiga kelompok yakni red devil hitam, red devil merah, dan red devil merah kehitaman. Red devil hitam dikenal sebagai individu "normal" dengan warna tubuh abu-abu hingga hitam, sedangkan red devil merah dikenal sebagai individu "gold" dengan warna tubuh jingga hingga merah (Barlow 1983, Dickman et al. 1988, Henning et al. 2013). Warna tubuh yang umum ditemui pada red devil adalah keabu-abuan dengan pola bintik, garis dan pita dikenal sebagai individu "normal" atau "dark", sedangkan individu "gold" diperkirakan sebanyak 8-10\% saja dan memiliki bentuk tidak menentu dengan pewarnaan jingga, kuning atau kadang-kadang putih (Barlow 1976). Red devil merah kehitaman pada penelitian (Henning et al. 2013, Sowersby et al. 205 dikategorikan sebagai fase transisi "normal" menuju "gold", ketika densitas melanofor mulai mengalami penurunan pada fase ini hingga tidak ditemukan lagi pada fase "gold".

Warna tubuh berkorelasi sangat kuat dengan karakter tingkah laku dan fisiologi seperti strategi reproduksi, agresi atau penyerangan, fungsi imun, dan respon stres (Barlow 1983). Perubahan warna dapat dipengaruhi oleh proses morfologi dan fisiologi. Perubahan warna karena proses morfologi terjadi karena adanya variasi konsentrasi pigmen kulit pada morfologi, densitas dan distribusi kromatofor, perubahan ini relatif lambat, beberapa hari atau minggu. Perubahan warna yang dipengaruhi oleh proses fisiologis terjadi sebagai dampak langsung faktor lingkungan, seperti pencahayaan pada migrasi pigmen, dan dapat terjadi sangat cepat dalam hitungan menit atau jam (Leclercq et al. 2010). Banyak hewan menggunakan pigmen karotenoid yang berasal dari sumber makanannya untuk pewarnaan dan imunitas tubuh. Namun, hipotesis tersebut ditemukan kontras pada ikan red devil. Peningkatan suplemen makanan karotenoid tidak memengaruhi pewarnaan dan peningkatan imunitas tubuh ikan. Ikan red devil diketahui mampu memelihara pewarnaan dan imunitas tubuh dengan kadar karotenoid yang rendah yakni $<10 \mathrm{mg} \mathrm{g}^{-1}$, yang menunjukkan 
bahwa diet karotenoid tidak membatasi sifat spesies ini. Selain itu, individu dengan warna tubuh "gold" diketahui memiliki lebih banyak karotenoid dalam jaringan kulit dan integumennya dibandingkan dengan individu "normal", tetapi individu "normal" memiliki konsentrasi karotenoid lebih tinggi pada cairan tubuhnya dibandingkan individu "gold” (Lin et al. 2010).

Semua individu memulai hidup dengan warna "normal", kemudian beberapa di antaranya (8-10\%) kehilangan sel-sel pigmen melanofora yang bertanggung jawab terhadap pewarnaan cokelat-hitam karena kematian sel-sel tersebut, yang mengakibatkan perubahan warna individu menjadi jingga hingga merah atau bahkan warna putih akibat hilangnya melanofora dan xantofora (Barlow 1976, Dickman et al. 1988). Fenomena ini juga dikendalikan oleh aliran atau pertukaran gen induk, meskipun dalam tingkatan yang rendah (McKaye \& Barlow 1976). Hasil penelitian tersebut sejalan dengan penelitian (Habibie et al. 2015) terhadap larva ikan red devil di Waduk Sermo yang ditemukan dalam satu warna "normal" saja. McKaye \& Barlow (1976) dan Dickman et al. (1988) menyebutkan waktu terjadinya perubahan pigmentasi warna bervariasi, mulai dari umur individu beberapa bulan, atau bahkan juga pada individu tertentu ditemukan ketika berumur sudah cukup tua (beberapa tahun). Henning et al. (2013) menemukan awal perubahan warna tubuh midas cichlid diketahui terjadi saat berumur tujuh bulan dan tidak bergantung kepada ukuran tubuh ikan tersebut.

Data panjang total sebelum dibakukan menunjukkan bahwa ikan red devil merah yang tertangkap memiliki rata-rata ukuran tubuh yang lebih besar dibandingkan dengan red devil hitam dan red devil merah kehitaman. Barlow
(1973) dalam penelitiannya menemukan adanya kompetisi antara individu "gold" dan "normal" yang dipelihara bersama dalam lingkungan terkontrol di laboratorium, di mana individu "gold" cenderung mendominasi dan tumbuh lebih cepat dibandingkan dengan individu "normal” (Barlow 1973). Beberapa keuntungan menjadi individu "gold" dibandingkan inividu "normal" di alam yakni lebih resisten terhadap penyakit (Barlow 1976), memijah pada ukuran yang lebih kecil (McKaye \& Barlow 1976), dan induk lebih sukses menjaga dan merawat anakan pada kedalaman yang sama (Barlow 1976). Meskipun individu "gold" memiliki tingkah laku yang tidak terlalu agresif tetapi ketika kondisi mendesak maka ikan ini akan cenderung lebih menyerang dibandingkan dengan sekedar mengancam (McKaye \& Barlow 1976).

Berdasarkan hasil analisis komponen utama, karakter morfometrik pembeda utama pada red devil di Waduk Sermo terletak pada karakter morfometrik sekitar kepala dan tubuh bagian tengah. Hasil analisis komponen utama tersebut semakin diperkuat oleh hasil analisis fungsi diskriminan yang menunjukkan bahwa karakter pembeda antarkelompok spesies merupakan karakter yang berada di sekitar kepala. Menurut (Elmer et al. 2010), midas cichlid pada setiap danau memiliki karakteristik bentuk tubuh masing-masing dan evolusi spesies sangat bergantung pada lingkungan hidupnya. Faktor lingkungan abiotik seperti kekeruhan, kedalaman, kemiringan, suhu air, dan kandungan kimiawi perairan danau menjadi faktor penting yang berpengaruh terhadap perbedaan bentuk tubuh spesies (Cole 1976). Selain itu, pengaruh tingkah laku dan karakter morfologi siklid seperti pengasuhan anak, seleksi jenis kelamin, desain fungsional, serta fenotipik dan polimorfisme 
ikut mendukung terjadinya spesiasi (Stiassny \& Meyer 1999, Salzburger 2009).

Warna tubuh tidak memiliki korelasi terhadap jenis kelamin, artinya baik jantan maupun betina ditemukan dalam semua fenotip warna red devil yang ada. Berdasarkan uji-t dan analisis diskriminan terhadap 21 karakter morfometrik diketahui bahwa betina dan jantan pada masing-masing kelompok memiliki beberapa karakter morfometrik yang berbeda secara signifikan. Karakter morfometrik pembeda utama pada ketiga kelompok spesies tersebut adalah pectoral fin-opercula. Karakter morfometrik lainnya yang menjadi pembeda utama betinajantan merupakan karakter-karakter morfometrik yang berada di sekitar kepala dan tubuh bagian tengah. Dengan demikian, red devil di perairan Waduk Sermo menunjukkan adanya dimorfisme seksual. Berdasarkan nisbah beberapa karakter morfometrik pembeda maka dapat dipastikan individu jantan memiliki pectoral fin-opercula dan eye diameter lebih kecil dan opercula-dorsal spine dan head length lebih besar dibandingkan dengan individu betina pada ukuran yang sama. Hasil penelitian tidak sejalan dengan Barlow (1976) yang menemukan tidak adanya perbedaan bentuk tubuh antara betina dan jantan (isomorfik) pada midas cichlid. Hal ini dapat dijelaskan karena perubahan kondisi lingkungan berdampak pada pola adaptasi ikan sebagai respons perubahan. Respons yang diberikan oleh suatu spesies sangat mungkin berbeda dengan spesies lainnya, termasuk bentuk tubuh dan ukuran beberapa bagian tubuh (Olufeagba et al. 2015).

Pengklasifikasian populasi red devil merah, red devil hitam, dan red devil merah kehitaman berdasarkan kesamaan karakter morfometrik dianalisis menggunakan analisis klaster.
Analisis klaster terhadap enam kelompok red devil jantan-betina di Waduk Sermo menghasilkan dendrogram yang mengelompokkan spesies ke dalam dua klaster. Klaster pertama beranggotakan kelompok red devil betina, sedangkan klaster kedua beranggotakan kelompok red devil jantan. Analisis pengelompokan menggunakan dendrogram ini konsisten dengan hasil persebaran karakter morfometrik berdasarkan analisis kanonikal yang juga membentuk dua centroid terpusat, semakin memperjelas terjadinya dimorfisme seksual pada spesies ini.

Berdasarkan pengamatan terhadap mitokondria DNA control region (mtDNA CR), ketiga kelompok red devil tersebut teridentifikasi sebagai A. amarillo (Stauffer \& McKaye 2002) berdasarkan pengamatan terhadap mitokondria DNA control region (mtDNA CR). Namun, secara morfologi, spesies ini tidak menunjukkan A. amarillo seperti yang telah dideskripsikan oleh (Stauffer Jr. \& McKaye 2002) sebagai spesies endemik di Danau Xiloá. Spesies A. amarillo tersebut hanya ditemukan dalam satu warna "normal" saja dan dideskripsikan memiliki warna kepala hijau bercampur kuning; bagian bawah tulang pipi bewarna kuning; bagian anterior memiliki gular berwarna kuning; bagian posterior bewarna jingga kemerahan; bagian interorbital berwarna hijau dengan dua bar interorbital hijau gelap; pre-opercula berwarna hijau; bagian posterior opercula berwarna merah, kuning atau jingga; tubuh berwarna hijau kekuningan atau kuning pada beberapa individu; sekitar 1/3 sisi lateral berwarna hijau, sekitar 1/3 bagian ventral berwarna hijau atau kuning, memiliki enam sampai delapan bar titik hitam, bar anterior memanjang sampai ke sirip punggung, titik hitam pada ekor memanjang sampai sirip ekor; sirip dorsal berwarna hijau atau abu-abu, posterior 

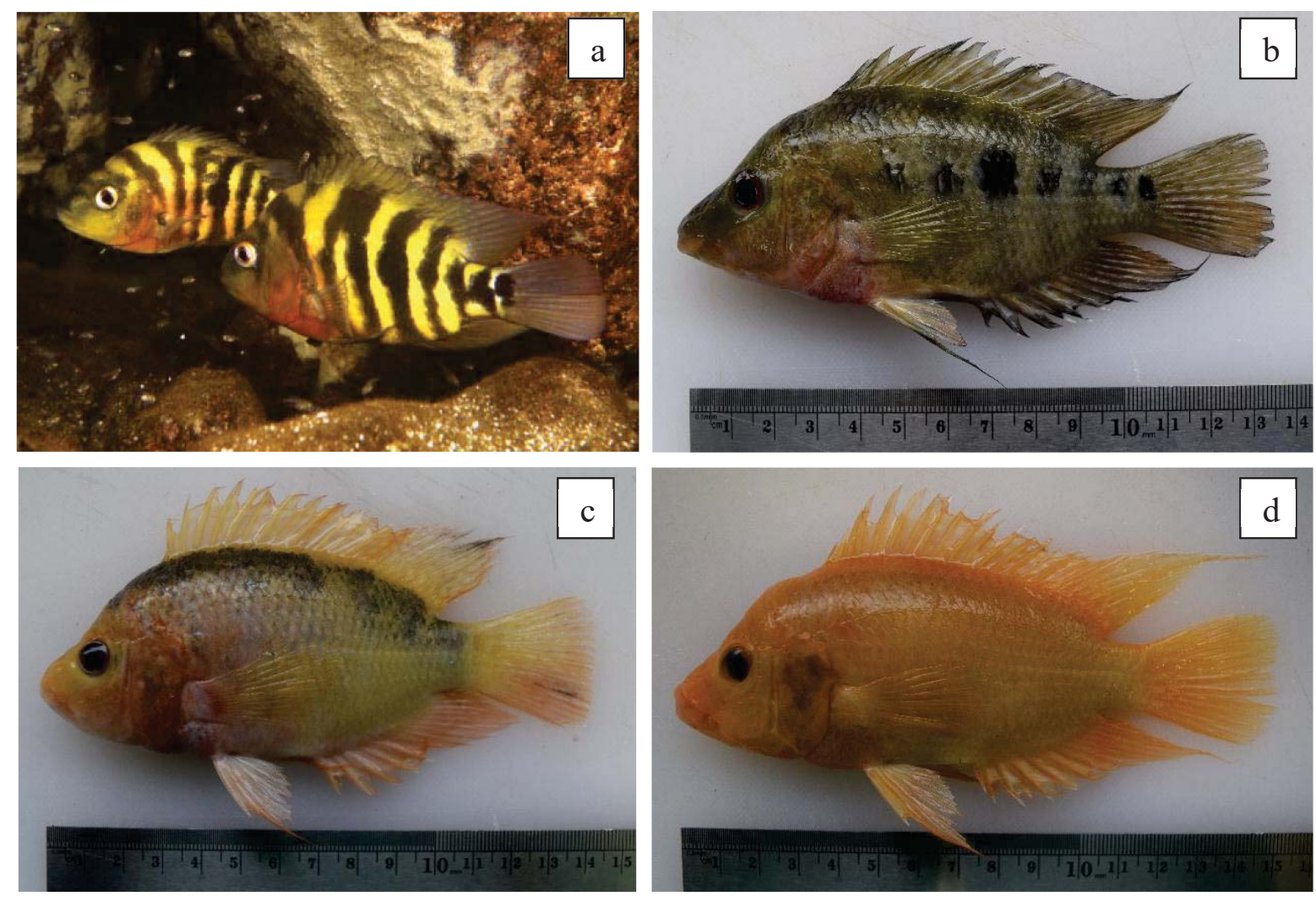

Gambar 7. a) A. amarillo (Stauffer Jr. \& McKaye 2002); b, c dan d) A. amarillo di Waduk Sermo

rays berwarna jingga pada beberapa individu, sirip perut berwarna hijau atau abu-abu dengan garis pertama sirip berwarna hitam, dan sirip dada berwarna kuning pudar (Stauffer Jr. \& McKaye 2002) (Gambar 7a)

Spesies A. amarillo yang teridentifikasi berdasarkan pengamatan terhadap mitokondria DNA control region di Waduk Sermo memiliki warna tubuh baik "normal" maupun "gold" dan tidak menunjukkan warna hijau kekuningan pada bagian-bagian tubuhnya (Gambar 7b;7c;7d). Hal tersebut dapat terjadi diduga karena proses adaptasi dan spesiasi spesies dengan lingkungan Waduk Sermo yang memiliki karakteristik lingkungan yang berbeda dengan Danau Xiloá. Identifikasi spesies red devil di Waduk Sermo sebagai A. amarillo menjadi identifikasi perta- ma secara genetik sekaligus mengoreksi penamaan spesies A. labiatus yang digunakan selama ini (Habibie et al. 2015) dan akan terus digunakan hingga ditemukan penelitian pembaharuan selanjutnya.

\section{Simpulan}

Ikan red devil menunjukkan fenomena polikromatisme yaitu red devil merah, red devil hitam dan red devil merah kehitaman. Karakter morfometrik menunjukkan terjadinya dimorfisme seksual pada red devil di Waduk Sermo. Individu jantan memiliki pectoral fin-opercula dan eye diameter lebih kecil, serta operculadorsal spine dan head length lebih besar dibandingkan dengan individu betina pada ukuran yang sama. Diagram kanonikal dan dendrogram 
konsisten mengelompokkan ketiga kelompok ikan tersebut sebagai spesies yang sama, namun terpisah berdasarkan jenis kelamin sehingga sangat nyata terjadi dimorfisme seksual. Secara genetik, tiga kelompok red devil tersebut teridentifikasi sebagai A. amarillo [Stauffer \& McKaye 2002] berdasarkan pengamatan terhadap mitokondria DNA control region (mtDNA CR).

\section{Persantunan}

Terimakasih disampaikan kepada seluruh pihak yang telah membantu sejak awal hingga selesainya penelitian serta penyusunan artikel ini.

\section{Daftar pustaka}

Barlow GW. 1983. The benefits of being gold: behavioral consequences of polychromatism in the midas cichlid, Cichlasoma citrinellum. Environmental Biology of Fishes, 8(3/4): 235-247

Barlow GW. 1976. The midas cichlid in Nicaragua. Investigation of the Ichthyofauna Nicaraguan lakes, 23: 333-359

Barlow GW, Munsey JW. 1976. The red devil-midas-arrow cichlid species complex in Nicaragua. Investigations of the Ichthyofauna of Nicaraguan Lakes, 24: 359-369

Barluenga M, Meyer A. 2010. Phylogeography, colonization and population history of the Midas cichlid species complex (Amphilophus spp.) in the Nicaraguan crater lakes. BMC Evolutionary Biology. 10: 326

Barluenga M, Meyer A. 2004. The Midas cichlid species complex: Incipient sympatric speciation in Nicaraguan cichlid fishes? Molecular Ecology, 13(7): 2061-2076

Barriga-Sosa I de los A, Jiménez-Badillo, MDL, Ibánez AL, Arredondo-Figueroa JL. 2004. Variability of tilapias
(Oreochromis spp.) introduced in Mexico: morphometric, meristic and genetic characters. Journal of Applied Ichthyology, 20(1): 7-14

Cole GA. 1976. Limnology of the Great Lakes of Nicaragua. In: Thorson TB (Ed.). Investigation of the Ichthyofauna Nicaraguan Lakes, 3: 9-15

Dickman MC, Schliwa M, Barlow GW. 1988. Melanophore death and disappearance produces color metamorphosis in the polychromatic Midas cichlid (Cichlasoma citrinellum). Cell Tissue Research, 253(1): 9-14

Elliott NG, Haskar K, Koslow JA. 1995. Morphometric analysis of orange roughy (Hoplostethus atalanticus) off the continental slope of southern Australia. Journal of Fish Biology, 46(1): 202-220.

Elmer KR, Kusche H, Lehtonen, TK, Meyer A. 2010. Local variation and parallel evolution: morphological and genetic diversity across a species complex of neotropical crater lake cichlid fishes. Philosophical Transactions of the Royal Society Biological Sciences, 365: 1763-1782

Gu DE, Mu XD, Xu, M, Luo D, Wei H, Li YY, Zhu YJ, Luo JR, Hu YC. 2016. Identification of wild tilapia species in the main rivers of south China using mitochondrial control region sequence and morphology. Biochemical Systematics and Ecology, 65(1): 100-107

Habibie SA, Djumanto, Rustadi. 2015. Penggunaan otolit untuk penentuan umur dan waktu pemijahan ikan red devil, Amphilophus labiatus [Günther, 1864] di Waduk Sermo, Yogyakarta. Jurnal Iktiologi Indonesia. 15(2): 87-98

Henning F, Jones JC, Franchini P, Meyer A. 2013. Transcriptomics of morphological color change in polychromatic Midas cichlids. BMC Genomics, 14(1): 171

Kitano J, Mori S, Peichel CL. 2007. Sexual 
dimorphism in the external morphology of the threespine stickleback (Gasterosteus aculeatus). Copeia 2007(2), 336-349

Kratochwil CF, Sefton MM, Meyer A. 2015. Embryonic and larval development in the Midas cichlid fish species flock (Amphilophus spp.): a new evodevo model for the investigation of adaptive novelties and species differences. BMC Developmental Biology, 15: 12

Kullander SO. 2003. Family Cichlidae (Cichlids). In: Reis RE, Kullander SO, Ferraris Jr CJ (Eds.). Check List of the Freshwater Fishes of South and Central America. Edipucrs, Porto Alegre, Brazil, pp. 605-654

Leclercq E, Taylor JF, Migaud H. 2010. Morphological skin colour changes in teleosts. Fish and Fisheries, 11(2): 159-193

Lin SM, Nieves- Puigdoller K, Brown AC, McGraw KJ, Clotfelter ED. 2010. Testing the carotenoid trade-off hypothesis in the polychromatic midas cichlid, Amphilophus citrinellus. Physiological and Biochemical Zoology: Ecological and Evolutionary Approaches, 83(2), 333-342

McKaye KR. 1980. Seasonality in habitat selection by the gold color morph of Cichlasoma citrinellum and its relevance to sympatric speciation in the family Cichlidae. Environtal Biology of Fishes, 5(1): 75-78

McKaye KR, Barlow GW. 1976. Competition between color morphs of the midas cichlid, Cichlasoma citrinellum, in Lake Jiloa, Nicaragua. Investigation of the Ichthyofauna of Nicaraguan Lakes, 34: 465-475

McKaye KR, Stauffer Jr JR, Van den Berghe EP, Vivas R, Lorenzo J, Perez L, McCrary JK, Waid R, Konings A, Lee W, Kocher TD. 2002. Behavioral, morphological and genetic evidence of divergence of the midas cichlid species complex in two Nicara- guan crater lakes. Cuadernos de Investigación de la U.C.L, 12: 19-47

Olufeagba SO, Aladele SE, Okomoda VT, Sifau MO, Ajayi DA, Oduoye OT, Bolatito OA, Nden DS, FabunmiTolase AS, Hassan T. 2015. Morphological variation of cichlids from Kainji Lake, Nigeria. International Journal of Aquaculture. 5(26): 1-14

Salzburger W. 2009. The interaction of sexually and naturally selected traits in the adaptive radiations of cichlid fishes. Molecular Ecology, 18(2): 169-185

Seehausen O, Van Alphen JJM. 1998. The effect of male coloration on female mate choice in closely related Lake Victoria cichlids [Haplochromis nyererei] complex). Behavavioral Ecology and Sociobiolgy, 42(1): 1-8

Sowersby W, Lehtonen TK, Wong BBM. 2015. Background matching ability and the maintenance of a colour polymorphism in the red devil cichlid. Journal of Evolutionary Biology, 28(2): 395-402

Stauffer Jr JR, McCrary JK, Black KE. 2008. Three new species of cichlid fishes (Teleostei: Cichlidae) from Lake Apoyo, Nicaragua. Proceedings of the Biological Society of Washington 121(1): 117-129

Stauffer Jr JR, McKaye KR. 2002. Descriptions of three new species of cichlid fishes (Teleostei: Cichlidae) from Lake Xiloá, Nicaragua. Cuadernos de Investigación de la U.C.L, 12: 1-18

Stiassny MLJ, Meyer A. 1999. Cichlids of the rift lakes. Scientific American, 280(2): 64-69

Turan C, Ergüden D, Turan F, Gürlek M. 2004. Genetic and morphologic structure of Liza abu (Heckel, 1843) populations from the rivers Orontes, Euphrates and Tigris. Turkish Journal of Veterinary and Animal Sciences, 28(4): 729-734

Wu L, Yang J. 2012. Identifications of cap- 
Polikromatik, dimorfisme seksual, dan redeskripsi spesies ikan red devil

tive and wild tilapia species existing in Hawaii by mitochondrial DNA control region sequence. PLoS One, 7(12): e51731 